\title{
TWENTY-THREE-YEAR LONG-TERM HEALTH OUTCOME AFTER THE WAR IN VUKOVAR
}

\author{
Dubravko Habek ${ }^{1}$, Tatjana Dujaković ${ }^{2}$, Jasna Čerkez Habek ${ }^{3}$ and Ivana Jurković ${ }^{4}$
}

\author{
${ }^{1}$ University Department of Obstetrics and Gynecology, Sveti Duh University Hospital, Croatian Catholic \\ University, Zagreb; ${ }^{2}$ Vukovar Health Centre, Vukovar; ${ }^{3}$ University Department of Internal Medicine, Sveti Duh \\ University Hospital, Croatian Catholic University, Zagreb; ${ }^{4}$ High Nursing School, Bjelovar, Croatia
}

SUMMARY - Results of the first research of this kind on the 23-year long-term outcome in children born during the war in Vukovar are presented. This retrospective clinical study surveyed the potential 23-year long-term consequences and morbidity of children born between May 1, 1991 and November 19, 1991, during the siege and occupation of Vukovar. Data were obtained from women having delivered their babies in that period and from delivery protocols of the Department of Gynecology and Obstetrics, Vukovar County Hospital. According to the survey and the data collected, there were 9 (3.98\%) preterm deliveries, 60 (81\%) of the total of 77 subjects were breastfed, 14 (19\%) were not breastfed, while three babies died in the postpartum period. However, the breastfeeding period was evidently shorter, as only 10 women breastfed for a period longer than 6 months, while the mean length of the breastfeeding period was 9.9 weeks, i.e. 2.5 months. Allergyrelated illnesses and proneness to infections in childhood and preschool age were found in $27.3 \%$ and $16.9 \%$ of children, respectively, while two children developed diabetes type 1 . One child had atopic diathesis, two started speaking after the age of two, one child started walking late (after 20 months) and started speaking after the age of two, one child had loud sound phobia, and one used to overreact and express anger in inconvenient situations, all of them being of female gender and born prematurely. Cognitive and attention disorders and stress reactions were found in $6.5 \%$ of the children. Regular elementary school education was completed by 74 (96\%) children, while three (3.8\%) children experienced failure at school due bad behavior, i.e. delinquency. At the age of 23, 34 (46\%) children had developed bad habits, i.e. 33 of them smoked, 2 were addicted to alcohol, whereas one was addicted to both smoking and alcohol. Forty (54\%) subjects did not use any harmful substances. Psychiatric disorders related to anxiety, depression or other illnesses were not found in this research. In conclusion, it should be noted that pregnant women who gave birth during the study period spent the first trimester of their pregnancy in a relatively peaceful pre-war period without acute stressors, so the long-term results and morbidity actually did not differ from those in the general population. The most important isolated risk factor was premature delivery with the known short-term and long-term consequences typical for premature delivery (perinatal mortality, slow neuromotor and cognitive development).

Key words: War; Croatia; Long term adverse effects; Outcome assessment (health care); Morbidity; Epidemiology

\footnotetext{
Correspondence to: Prof. Dubravko Habek, $M D, P h D$, University Department of Obstetrics and Gynecology, Sveti Duh University Hospital, Sveti Duh 64, Croatian Catholic University, Zagreb, Ilica 242, HR-10000 Zagreb, Croatia

E-mail: dubravko.habek@os.t-com.hr; dhabek@unicath.hr

Received August 13, 2015, accepted October 6, 2015
}

\section{Introduction}

Short-term and long-term consequences of unfavorable conditions in the perinatal age, including the psychosocial stress caused by war, are certainly connected. The war aggression against the Republic of 
Croatia that was initiated in summer 1991 by the Yugoslav Army and paramilitary Serbian troops has had long lasting effects on public health parameters. Vukovar, a town in the eastern part of Slavonia, located on the border with the aggressor, managed to resist constant attacks for several months, after which it was occupied and finally taken over by the aggressor on November 18, 1991, which involved proven mass crimes and post-war tragic events (murders, war camps, acts of rape, missing persons). All daily activities in the occupied town took place in shelters, while the Vukovar Hospital became a sort of a small underground town. Its activities were carried out in the basement area of the hospital that is now known as the Homeland War Medicine Museum. Until November 15, 1991, more than 1,700 wounded persons (soldiers and civilians) were operated on in the hospital premises, which included three operating rooms, intensive care unit and delivery room with patients being accommodated in all rooms, a kitchen and a laundry room ${ }^{1,2}$. Pregnant women mostly spent their pregnancy in shelters in minimal hygienic and nutrition conditions, constantly surrounded by war activities outside the shelters, in a hostile environment and exposed to constant war stress lasting for several months ${ }^{1,3,4}$.

In the first research of this kind, results of the 23year long-term outcome in children born in war conditions are presented.

\section{Material and Methods}

This retrospective clinical research surveyed the potential long-term consequences and morbidity 23 years after the siege and occupation of Vukovar. Data on demography, late perinatal outcome and long-term development/outcome (cognitive and psycholinguistic disorders, morbidity due to allergic or infectious diseases) of children were obtained from the women having delivered their babies between May 1, 1991 and November 19, 1991 and from delivery protocols of the Department of Gynecology and Obstetrics, Vukovar County Hospital. The Ethics Committee of the Vukovar County Hospital granted approval for conducting this research. The research included a total of 77 (34\%) women who gave birth in the aforementioned period. Regarding the rest of 149 women, 118 were unavailable (mostly fugitives, refugees, war camp prisoners or missing persons) with unknown residence, while 31 women refused to participate in the research for personal reasons (Table 1).

Table 1. Demographic data and 23-year long-term outcome after the war (2014)

\begin{tabular}{|l|r|r|}
\hline N=77 & Number & $\%$ \\
\hline Socioeconomic status & & \\
- good & 54 & $70.10 \%$ \\
- average & 23 & $29.90 \%$ \\
- poor & 0 & $0 \%$ \\
\hline Postpartal course (puerperium) & & \\
- normal & 70 & $90.9 \%$ \\
- puerperal hemorrhage & 7 & $9.1 \%$ \\
- other & 2 & $2.6 \%$ \\
\hline Breast feeding & & \\
- yes & 60 & $81 \%$ \\
- no & 14 & $19 \%$ \\
\hline Duration of breastfeeding & & \\
2-4 weeks & 22 & $28.5 \%$ \\
5-8 weeks & 9 & $11.6 \%$ \\
9-16 weeks & 13 & $16.8 \%$ \\
17-24 weeks & 6 & $7.7 \%$ \\
>25 weeks & 10 & $12.9 \%$ \\
\hline Psycholinguistic and & & \\
cognitive disorders & & \\
(all preterm deliveries) & & \\
\hline Small children and preschool & & \\
children (childhood) & & \\
- allergic diseases & & \\
- predisposition to infections & 21 & $27.3 \%$ \\
- diabetes mellitus type 1 & 2 & $2.59 \%$ \\
- hernia & & $1.29 \%$ \\
- epilepsy & & $1.29 \%$ \\
\hline School age & & \\
- delinquency/misbehavior & 3 & $3.8 \%$ \\
- normal behavior & & $96.1 \%$ \\
\hline Harmful habits at the age of 23 & & \\
- yes & & \\
- smoking & & \\
- drinking (alcohol) & & \\
- none & & \\
\hline & & \\
\hline
\end{tabular}




\section{Results}

According to the survey and the data, there were 9 (3.98\%) preterm deliveries, including three babies that died after delivery due to very low birth weight. The postpartum period was normal in $90.9 \%$ of parturients, while $7(5 \%)$ of them experienced prolonged bleeding during the postpartum period, one of them during transportation to a Serbian war camp. Fiftyfour (70.10\%) subjects were of good socioeconomic status, while $23(29.90 \%)$ were of middle socioeconomic status. Sixty (81\%) of the total of 77 subjects breastfed, 14 (19\%) did not breastfeed, while three women had babies that died in the postpartum period. However, the breastfeeding period was evidently shorter, as only 10 women breastfed for a period longer than 6 months, while the mean length of the breastfeeding period amounted to 9.9 weeks, i.e. 2.5 months. Allergy-related illnesses and proneness to infections in childhood and preschool age were found in $27.3 \%$ and $16.9 \%$ of children, respectively, while two children developed diabetes type 1 . One child had atopic diathesis, two started speaking after the age of two, one child started walking late (after 20 months) and started speaking after the age of two, one child had loud sound phobia, and one used to overreact and express anger in inconvenient situations, all of them being of female gender and born prematurely. Cognitive and attention disorders and stress reactions were found in $6.5 \%$ of the children. Regular elementary school education was completed by 74 (96\%) of them, while three (3.8\%) children experienced failure at school due bad behavior, i.e. delinquency. At the age of 23, 34 (46\%) of them had developed bad habits, i.e. 33 of them smoked, 2 were addicted to alcohol, whereas one of them was addicted to both smoking and alcohol. Forty (54\%) subjects did not use any harmful substances. Psychiatric disorders related to anxiety, depression or other illnesses were not found in this research.

It is interesting to note that none of 77 subjects stated any data on the period of living as a refugee or fugitive, rape or staying at a war camp, even 23 years after the war and despite the known facts regarding mass transportations to war camps, rapes and deportations.

\section{Discussion}

Long-term consequences of unfavorable perinatal events, especially psychosocial stress caused by war in perinatal age, on later life, health and individual socioeconomic outcome are known, thoroughly researched and proven, such as temporary or permanent psychiatric, cognitive and psychosocial disorders, cardiovascular morbidity, diabetes, etc. ${ }^{4-7}$.

Short and insufficient breastfeeding is certainly one of the proven causes of allergic illnesses and susceptibility to infections in childhood and preschool age, which was recorded in $27.3 \%$ and $16.9 \%$ of the study children, respectively, while two children developed diabetes type 1 . In our research, only $12.9 \%$ of mothers breastfed longer than 25 weeks. Moro ${ }^{8}$ performed a research related to the war in Bosnia among 14.3\% of children born with intrauterine growth restriction (IUGR) and showed that 17 children were breastfed beyond the first year of life, while 31 children were breastfed in the first year, so infant mortality and morbidity in a part of Sarajevo remained unaltered. The author interprets this as the result of breastfeeding and infant supplementation. In the post-war time, an increased incidence of tuberculosis among children was indicated in eastern Slavonia, which the authors associated with migrations and post-war events 9

Prenatal maternal chronic stresses accompanied by especially low social conditions resulted in an increased incidence of depression during pregnancy, increased incidence of premature deliveries, and development of IUGR, which in total caused increased perinatal morbidity (especially neuromotor impairments) and mortality ${ }^{10}$. It has been shown that increased concentrations of stress hormones, cortisol and catecholamines, have an impact on fetal brain receptor system during development and alter topobiochemistry and receptor relations. Thus, maternal anxiety in the early development of fetal brain is especially harmful for later cognitive development, behavioral problems and emotions, and for lateralization of hand orientation (righthanded/left-handed $)^{11}$.

Jakobovits ${ }^{12}$ states that neurotic or autistic children who had adverse perinatal outcome frequently develop psychopathy in adulthood, and finds connection between maternal stress during pregnancy and subsequent abnormal psychosocial development. British psychiatrists carried out a retrospective study 
which demonstrated that maternal stress during pregnancy increased the risk of schizophrenia later in life. They compared war stress, panic and depression in pregnant women, especially in the first trimester of pregnancy, who were witnesses of the invasion of The Netherlands in $1940^{13}$. Recent studies also indicate a higher prevalence of posttraumatic stress, anxiety and depression, and affective disorders in adults who were born in Jerusalem between 1964 and 1976, whose mothers were subject to war stress in the first quarter, especially in the third month of pregnancy ${ }^{14}$. The work of Malaspina et al. ${ }^{15}$ also shows that the mother's gestational stress caused by the Arab-Israeli war in 1967 in the first quarter turned out to represent a significant risk factor for schizophrenia, more often in females. Feldman and Vengrober ${ }^{10}$ established the diagnosis of posttraumatic stress disorder in $37.8 \%$ of children aged 1.5 to 5 subject to the war in the Gaza Strip, while Meijer ${ }^{16}$ proved the connection between the wartime stress and psychiatric disorders, including children's regressive, non-affiliative and dissocial behavior. In our study, no psychiatric morbidity at the age of 23 was found after pregnancy and childbirth in war conditions, while psycholinguistic and cognitive impairment was found in prematurely born female children. One case of epilepsy in childhood was recorded in our study. In their study reports, Bosnjak et al. conclude that stressful life (war) events can be provocative factors for the occurrence of epileptic seizures ${ }^{17}$. Furthermore, cardiovascular morbidity at the age of 23 was not found in our study, whereas Alastalo et al. pointed to increased cardiovascular morbidity and emergence of type 2 diabetes in adults exposed in childhood to war stress in World War $\mathrm{II}^{18}$. Perhaps our subsequent research shall prove otherwise or confirm the current findings.

It should be noted that pregnant women who gave birth during this period spent the first trimester of their pregnancy in a relatively peaceful pre-war period without acute stressors, so the long-term results and morbidity actually did not differ from those in the general population. Although pregnant women spent their third trimester subject to constant shelling of the city, inadequate nutrition and minimum hygienic conditions, there were no cases of IUGR type II and long-term complications associated with intermediary metabolism, except for two cases of juvenile diabetes mellitus, but found in eutrophic children. The most important isolated risk factor was premature delivery with the known short-term and long-term consequences typical for premature delivery (perinatal mortality, slow neuromotor and cognitive development).

\section{References}

1. Habek D, Kovačević M. Adverse pregnancy outcomes and long-term morbidity after early fetal hypokinesia in maternal smoking pregnancies. Arch Gynecol Obstet. 2011;3(7):491-6. doi: 10.1007/s00404-010-1395-3. Epub 2010 Feb 27.

2. Simic S, Idrizbegovic S, Jaganjac N, Boloban H, Puvacic J, Gallic A, Dekovic S. Nutritional effects of the siege on new-born babies in Sarajevo. Eur J Clin Nutr. 1995;49:Suppl 2:S33-6.

3. Dujaković T. Short-term and long-term results after unfavorable perinatal events during the war in Vukovar. Nursing thesis. Technical College in Bjelovar; 2014.

4. MatošI. Surgery in Vukovarwar. Croat MedJ.2011;52(2):21820.

5. Lee C. In utero exposure to the Korean War and its longterm effects on socioeconomic and health outcomes. J Health Econ. 2014;33(8):76-93. doi: 10.1016/j.jhealeco.2013.11.002. Epub 2013 Nov 21.

6. Hadi F, Llabre MM, Spitzer S. Gulf War-related trauma and psychological distress of Kuwaiti children and their mothers. J Trauma Stress. 2006;19(5):653-62.

7. Jensen PS, Shaw J. Children as victims of war: current knowledge and future research needs. J Am Acad Child Adolesc Psychiatry. 1993;32(4):697-708.

8. Moro D. Birth weight and breast feeding of babies born during the war in one municipal area of Sarajevo. Eur J Clin Nutr. 1995;49 Suppl 2:S37-9.

9. Aberle N, Bublić J, Ferić M, Bukvić B, Simić A, Trtica B, Blazević V, Boranić M. Increasing rate of childhood tuberculosis in a region of east Croatia. Pediatr Int. 2007;49(2):183-9.

10. Feldman R, Vengrober A. Posttraumatic stress disorder in infants and young children exposed to war related trauma. J Am Acad Child Adolesc Psychiatry. 2011;50(7):645-58. doi: 10.1016/j.jaac.2011.03.001. Epub 2011 Apr 29.

11. Glover V, O'Connor TG, Heron J, Golding J. Antenatal maternal anxiety is linked with atypical handedness in the child. Early Hum Develop. 2004;79:107-18.

12. Jakobovits AA. Fetal ethology and its relevance to perinatal medicine. Zbl Gynäkol. 2001;123(4):375-2.

13. van Os J, Selten JP. Prenatal exposure to maternal stress and subsequent schizophrenia. Br J Psychiatry. 1998;172:324-6.

14. Kleinhaus K, Harlap S, Perrin M, Manor O, Margalit-Calderon R, Opler M, Friedlander Y, Malaspina D. Prenatal stress 
and affective disorders in a population birth cohort. Bipolar Disord. 2013;15(1):92-9. doi: 10.1111/bdi.12015. Epub 2012 Nov 29.

15. Malaspina D, Corcoran C, Kleinhaus KR, Perrin MC, Fennig S, Nahon D, Friedlander Y, Harlap S. Acute maternal stress in pregnancy and schizophrenia in offspring: a cohort prospective study. BMC Psychiatry. 2008;8:71. doi: 10.1186/1471-244X-8-71.
16. Meijer A. Child psychiatric sequelae of maternal war stress. Acta Psychiatr Scand. 1985;72(6):505-11.

17. Bosnjak J, Vukovic Bobic M, Mejaski-Bosnjak V. Effect of war on the occurrence of epileptic seizures in children. Epilepsy Behaviour. 2002;3:502-9.

18. Alastalo H, Raikkonen K, Pesonen AK, Osmond C, Barker DJ, Kajantie E, Heinonen K, Forsen TJ, Eriksson JG. Cardiovascular health of Finnish war evacuees 60 years later. Ann Med. 2009;41(1):66-2. doi: 10.1080/07853890802301983.

Sažetak

\section{DVADESETTROGODIŠNJI DUGOROČNI ISHOD NA ZDRAVLJE DJECE ROĐENE TIJEKOM RATA U VUKOVARU}

\section{Habek, T. Dujaković, J. Čerkez Habek i I. Jurković}

U ovom prvom istraživačkom radu prikazuju se rezultati 23-godišnjega dugoročnog ishoda na zdravlje djece koja su rođena u ratnim uvjetima tijekom okupacije grada Vukovara. U istraživanju je sudjelovalo 77 (34\%) žena koje su rodile prema protokolu Ginekološko-porođajnoga odjela vukovarske bolnice od 1. svibnja do 19. studenoga 1991. Od ostalih 149 žena sudbina njih 118 nije poznata (mahom prognanici, izbjeglice, logoraši ili nestali) s nepoznatim boravištima, dok 31 žena nije željela sudjelovati u istraživanju iz osobnih razloga. Prijevremenih porođaja prema anketi i podatcima bilo je 9 (3,98\%), od čega je troje djece umrlo nakon porođaja zbog vrlo niske porođajne težine. Dojilo je 60 (81\%) žena, 14 (19\%) nije dojilo, od kojih tri zbog smrti djeteta u postpartalnom razdoblju. No, duljina dojenja evidentno je bila skraćena, jer je svega 10 žena dojilo >6 mjeseci, a prosječna duljina dojenja bila je 9,9 tjedana, odnosno 2,5 mjeseca. Alergijskih bolesti i sklonosti infekcijama u dječjoj i predškolskoj dobi bilo je u 27,3\% odnosno $16,9 \%$ djece, dok je dijabetes tipa 1 razvilo dvoje djece. Kognitivne, poremećaje pažnje i reakcije na stres imalo je 6,5\% djece ispitanica. Uredno osnovnoškolsko obrazovanje završilo je njih 74 (96\%), dok je troje (3,8\%) djece imalo školski neuspjeh zbog lošeg ponašanja, odnosno delinkvencije. Štetne navike u 23. godini života imalo je njih 34 (46\%) i to pušenje 33, alkohol 2, a pušenje i alkohol jedno, dok 40 (54\%) ispitanih nije konzumiralo nikakve štetne tvari. Psihijatrijskih poremećaja u vidu anksioznosti, depresije ili drugih bolesti nije u ovom istraživanju pronađeno. U zaključku, valja naglasiti da su trudnice koje su rodile u ovom razdoblju I. tromjesečje trudnoće provele u relativno predratnom mirnom razdoblju bez akutnih stresora pa dugoročni rezultati i pobol zapravo ne odstupaju od onih u općoj populaciji. Kao najznačajniji izolirani čimbenik rizika bio je prijevremeni porođaj s poznatim kratkoročnim i dugoročnim posljedicama uobičajenim za uranjeno rađanje (perinatalna smrtnost, usporeni neuromotorni i kognitivni razvoj).

Ključne riječi: Rat; Hrvatska; Dugoročni nepovoljni učinci; Ishod zdravstvene skrbi, procjena; Morbiditet; Epidemiologija 